Юлиян Тамаш

UDK 821(497.11)-14

Универзитет у Новим Садзе

Филозофски факултет

Оддзелєнє за русинистику

tamasjulijan@gmail.com

\title{
ЛЕМКІВСЬКИЙ СУБСТРАТ В ПОЕЗІЇ Б. І. АНТОНИЧА І Й. ГАРАСИМОВИЧА
}

\begin{abstract}
Анотація: Богдан Ігор Антонич (1909-1937) пише поезію українською, а Ї. Гарасимович (1933-1999) польською мовою. Без огляду на приналежність різним національним і поетичним традиціям, їм спільна мифотворчість природи. Оба плекають поетику простору. Перший називає її зеленою біблією, другий - країною лагідності. Їм спільний лемківський природний, культурний і поетичний субстрат. Під лемківським субстратом розуміємо лат. scintilla lirica - коломийка, краков'як, в основі емоціоналізації світу, відсутність героїчної моделлі світу, розщеплення суспільного і історичного єства поміж цивілізаційними моделяями Сходу і Заходу, приналежність греко-католицькій церкві в материкових землях та в россіянні як творення недокінченого екуменізму, посередництвом якого здійснювалася денаціоналізація лемків на рахунок державотворних народів в оточенні. В цих межах українська культурна традиція переважає, хоча у материкових землях і у розсіянні з'явлюються перехідні форми наближення східнослов'янської основи до західнослов'янських та південнослов'янських традицій.

Ключові слова: Б. І. Антонич, Ї. Гарасимович, національна поетика, поетика простору, мифотворчість природи, простір щастя, культурний субстрат, індивідуальна поетика, епіклеза.
\end{abstract}

Вважаємо, що на цьому місці немає необхідності пояснювати значення етноніма лемко чи лемки. Щодо цього заслуговують на увагу праці провідних учених дослідників, таких як: В. Гнатюк (Гнатюк, 19851-1988) С. Цамбел (Czambel, 1906), М. Мушинка (Мушинка, 1988), Л. Белей (Белей, 2016). Багато матеріалів можна знайти в польському збірнику Lemkowie (1983) та двотомнику праць Лемківщина (1988). Я також писав на цю тему у своєму дослідженні Чому руснаців / русинів з Бачки сліg вважатии часиииною українськоїо нароgу, яке в кінці цього року вийде в Науковому збірнику Музею украӥнської кульйури в Свиянику, разом з матеріалами з Міжнародної наукової конференції "Українці в історії і культурі Карпат", яка відбулася 8-9 квітня 2016 року. 
Слід сказати, що менш за все в цих працях наголошується той факт, що лемки, на відміну від гуцулів та бойків, що населяли східні схили Карпатських гір, належали до західної української діаспори поділеної на більш дрібні анклави, які протягом століть жили в різних державах, під сильним регіональним впливом держав, до яких вони належали і чиї кордони й назви часто змінювалися протягом століть. Таким чином, з часом в лемків не тільки послаблювалось усвідомлення своєї української ідентичності, але й регіональна лемківська спільнота тяжіла до ідентичності та культури країн, в яких вони жили.

Ось, чому я говорю про лемківський субстрат, тобто архаїчні пережитки лемківської регіональної ідентичності, яку ще можна знайти в матеріальній культурі, але яка вже в духовній культурі в основному покрита шарами забуття, процесами асиміляції чи акультурації в межах окремих держав. Особливо серйозними причинами, що призвели до втрати лемківської регіональної ідентичності були: полонізація (операція "Вісла"), угоризація (уздовж басейну річки Тиса, як камінці в полі, розкидані греко-католицькі парафії з віруючими угорської національності), словачення (віруючі грекокатолицької чи православної віри, а за національністю словаки), інтернаціоналізація під впливом більшовизму та русифікація під впливом російської православної церкви Московського патріархату і т.д.

Тепер, щодо наших поетів, обидва по походженню лемки, але В. І. Антонич (1909-1937) писав українською мовою, а Ї. Гарасимович (1933-1999) польською мовою. Нам невідомо, чи Гарасимович читав твори Антонича, тому ми не можемо говорити про вплив одного поета на другого. Ми будемо розглядати їх згідно теорії і практики історичних та типологічних аналогій В. М. Жирмунського на поетичному рівні, смислові відносини подібності або відмінності, де відмінності чи інновації з аксіологічної точки зору, розглядаються на основі подібності. Обидва письменника реалізували себе як поети в своїх національних традиціях і їх високо цінували. Незалежно від приналежності до різних національних поетичних традицій, ім була притаманна міфотворчість природи. Обидва плекали поетику художнього простору. Перший називає їі зеленим Єваніелієм, другий країною лайіgносӣi. Спільним для них є лемківський природний, культурний, антирелігійний і поетичний субстрат. Під лемківським субстратом маємо на увазі: лат. scintilla lyrica (коломийка, краков'як, шансон) емоційне сприйняття світу; відсутність героїчної моделі світу; розрив історичної і власної особистості серед цивілізаційних моделей Сходу і Заходу; уникнення приналежності до греко-католицької церкви в своїх країнах і за кордоном, а також запровадження незакінченого екуменізму, за допомогою якого проводилась денаціоналізація лемків на користь народів регіону. 
У обох поетів переважають східнослов'янські культурні традиції, хоча в країнах їхнього проживання і діаспорі з'являються перехідні форми наближення східнослов'янського грунту до західнослов'янських та південнослов'янських традицій.

Коротко зупинюсь на тому, що написано про поезію Антонича і Гарасимовича.

Антонич вірив у вічні закони маиееринсиива Землі і синівстива Люgини. Він вірив в ідею про ноосферу - сферу розуму, яка гармонізує відносини людини з природою, знаходячи їх у філософії П. Таяра, де Шардена, В. Вернадського. Цей шлях філософії, завдяки своїй природі і функції, поетичній мові, природі речей, з самого початку готувала поезія своєю міфотворчістю. У стародавні часи, усі важливі думки людина виражала різними способами римування, тобто у віршованій формі, навіть філософські та історичні. Як це не парадоксально, але оповідання, як мистецтво слова, є молодшим від вірша. Сила біблійних текстів, так званих paralelismus membrorum, християнського канонічного Євангелія як і Зеленоїо Єваніелія Антонича полягає в тому, що характер вплітається в долю, а доля залежить від характеру. Як у людей, так і в природі. Тому міфотворчість природи є міфом, який згідно А. Жолеса завжди говорить про важливі речі щодо формування людини і світу, навіть щодо опосередкованого впливу елементів природи, незайманих людським розумом, та рукою.

Написані статті про вплив Тичини, Вітмена, Тагора, Пришвіна, Чехова, Лорки на поезію Антонича, проте він переніс усі ці порівняння і залишився собою, своєрідним лемком, українським поетом. На мій погляд, з точки зору історичних і типологічних аналогій, більш важливим $є$ порівняння творчості

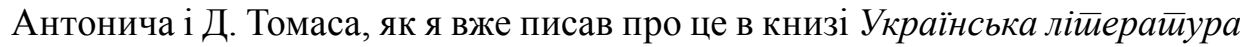
між Схоgом і Захоgом (Татаš, 2002), і зараз, в своїх підсумкових зауваженнях ще раз наголошу важливість розуміння того, чому сьогодні я розглядаю лемківський субстрат в Антонича і Гарасимовича.

Про віру Антонича в ноосферу свідчать окремі його вірші, такі як звер-

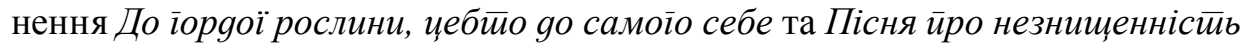
матеиерії. В обох віршах Антонич називає себе рослиною. Рослина символізує накопичену сонячну енергію та воду - тобто елементи, з яких Господь створив світ. Разом з чоловічим началом означає зростання, як про це говорить псалом 144.12: „Нехай наші сини молоді як рослини пишно зростають“. Рослинний світ $є$ фундаментальним символом єдності життя. В усіх цивілізацях представлено перехід рослинного в тваринний світ, земного в божественний, і навпаки.

Особливо цікавим $є$ те, як наші поети, не згадуючи Бога, через міфотврчість природи повертаються до нього, адже ранні критики Антонича, осо- 
бливо Тіверець і Костельник, вважали, що наскільки він в своїй душі втратив Бога, настільки він в своїх творах втратив своє поетичне слово. Антонич був лемком і українцем, але був хрещений в баптистській церкві, після дорікань написав книгу про Бога, але вона ніколи не була видана. Сам про себе говорив що: „Антонич був хрущем і жив колись на вишнях, на вишнях тих, що їх оспівував Шевченко“. Отже, для Антонича Прироga це - його Церква, а Поезія це - його Літиурїія. Він як і Шевченко - український сільський Схід без Заходу. Можемо зробити висновок, що Антонич, як і Д. Томас у вірші Переg болем / A grief ago, постійно спотикаючись об Бога - за словами самого Антонича, він співає „про вітражі і пейзажі“, а Гарасимович, згадуючи Бескиди, лемківські села і кладовища, з ікон виймає образи святих і поселяє їх серед своїх міських краківських сучасників - так і не змігши ні обійти Бога ні втекти від нього, як, зрештою, і Шевченко. Про це свідчить вірш Антонича Зелена віра

Зелений Бог рослин та звірів

учить мене п'янкої віри,

релігії ночей весінніх,

коли прапервні у кипінні,

у вічній зміні все незмінні.

(Релігії ночей кипучих,

Коли гримлять рослинні тучі).

Зелений Бог буяння й зросту

зітре на попіл мої кості,

щоб виростало, щоб кипіло

п’янких рослин зелене тіло.

Хто ти, що клониш чола куряв, вогонь, чи бог, ли птах, чи бур'я?

\section{4 березня 1936}

Повне поетичне визнання Антонич отримав у 1989 році, опублікувавши збірник вибраних критичних статей щодо своєї власної творчості. Гарасимович з самого початку - зі зламом доктрини соціалістичного реалізму - був загальноприйнятий завдяки свіжості своїх поетичних образів, зокрема через своє насмішливе ставлення до окостенілих і фальшивих цінностей міста i до польського політичного істеблішменту старих, а особливо новопечених панів. Прийнятий університетською критикою, та завдяки впливовому Ка- 
зимиру Віку його вірші перекладались багатьма мовами і вийшла збірка його творів. Лемківським субстратом, у цьому випадку стала не тільки згадка про дитинство як юність людства, але і шок гротеску і самоіронії Війона, Брейгеля, Сальвадора Далі та де Кіріко.

Gdy spat

\section{Mit o Świętym Jerzym}

mój patron

święty Jerzy

z choragwi jego

zrobitem

czerwony wsyp

blachę groźna

ctlopu dałem

na pokrycie stajenki

smoka

w krowe zamienitem

czasem

siarka buchajqca

pióropusz

$w$ lesie

na gnieździe

posadzitem

budzi sie

mój patron

gdzie mit

$w$ robocie

gdzie pióropusz

jajka znosi

gdzie zbroja

na dachu

drzemie $w$ upale

gdzie choragiew

pod wójtowa glowa

itak

cóz swięty

zboźe zaczat

zwozić,

izbę malować

konia dokupit 
drugiego.

Цей шок найкоротше і найточніше передає Петар Вуйчич, перекладач віршів Гарасимовича на сербську мову. У святого Джурджа, свого однойменця і покровителя, він вкрав прапор, плащ і щит, щитом накрив стайню, грізного дракона цього святого перетворив в корову. В кінці купив ще одного коня, як кожен, здавалося б, багатий селянин. Святому Франциску дав покататися на велосипеді. Так Гарасимович представляє польський західний гротеск Еразмуса Роттердама, Війона і Рабле, Крлежі та його Балаgи Пейрииі Керемйухи. Поет повідомив читачів і громадян про те, що його прадід Гарасим був хитрим, підступним як диявол і поважним як Пантократор, українським селянином. Він відкрив красу лемківсько-українських церков і кладовищ, прихованих у непрохідних лісах, зарослих розбійницькими, календарними і святковими первісними міфами і легендами, оповив їх живою фантазією, вкинув їх в наше повсякдення, вдихнув в них життя своїм могутнім поетичним і творчим хистом. Тому Гарасимовича слід вважати українським Сходом. Про те, що мова йде про лемківський субстрат, залишок одного, наче дитинство дорогоцінного, зникаючого і ніколи повністю не розвиненого вільного світу - про запущені могили предків, які ніхто давно вже не відвідує, а тільки осінь палить їм свічки - свідчить вірш Гарасимовича На лемківському клаgовищі.

Na cmentarz temkowski

Oto cmentarz

Zielem zarosty

Oto poręba

po krzyźach zwalonych

wiatrlom

świętego drzewa

Oto cmentarze Łemków

w Zlockiem 3

w Szczawniku

w Leluchowie

Oto śpia na podtodze

dawno juź spróch niatej

bez krzyźas nad glowa 


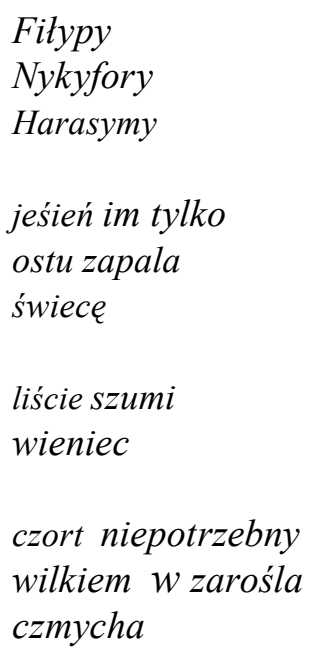

Про те, що Антонич був не тільки хрущем на вишнях Шевченка, а й знавцем української поетичної традиції говорить його Коломийка ирро весну, яка одночасно $€$ і віршем, і куплетом, і літературним жанром Scintilla lirika, на який в українському літературознавстві раніше не звертали увагу.

\section{Коломийка}

Віє вітер, віє буйний, віє за іорою,

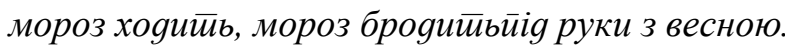

В річиі риби, в иоло скиби дощу з неба ироосяйь,

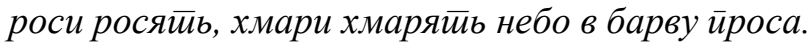

Помазала шляхи зливарозкислим болойом, йлуіи риюе̄ь йлай, мужииьким йахне йоле йойом.

Сірий ранок ніч розколе, зїасне сон на квішіі.

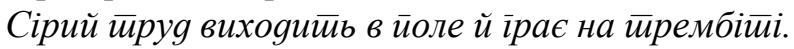

Тепер, давайте повернемося до відповіді на питання про те, як наші поети оспівуючи природу повертаються назад до Бога, навіть якщо його недвозначно обходять. У цьому нам допоможе пісня Д. Томаса, чиї перші рядки наступного змісту: "І цей хліб, котрий я ломаю, був вівсом/ і вино це на чужому винограді / наливало свої плоди ...", а останні "Пийте моє вино, 
ламайте мій хліб.” Хоча широко прийнятою є думка критиків, що у вищезгаданому вірші мова йде про перехід Д. Томаса з метафізичних поетів до поетів-пророків, але ніхто не помітив, що останній куплет нагадує епіклезу - обряд, яким в літургії передається свята таємниця, а саме: Дух Святий сходить на жертовний хліб / просфору / нафору і вино - тобто Тіло і Кров Христові. Особливість Томаса полягає в тому, що він Тіло і Кров Христові, причастям (пісня, поезія) за допомогою людини / поета, вертає природі. Тобто, він говорить про повернення матерії, рослинного світу, створених Богом, до праелементу буття, абсолюту. Природа стирає людське страждання з причини первородного гріха причастям, віршем як епіклезою. ПОЕТИКА ПРОСТОРУ ЦЕ - ПРОСТІР ЩАСТЯ І ОЧИЩЕННЯ ВІД ГРІХІВ ICTOPIÏ. Припустимо, що ми це першими зрозуміли й описали. І це, лежить в основі індивідуальної поетики і Д. Томаса, і Б. І. Антонича, і Й. Гарасимовича.

\section{ЛІТЕРАТУРА:}

Антонич, Б. І. (1938). Зелена Сваніелія. Львів.

Антонич, Б. І. (1989). Поезії. Київ: Радянський письменник.

Белей, Лю. (2016). Мовне очуднення як інструмент маніпулятивного творення русинської мови. Мовознавстиво, № 3. Київ, 13-30.

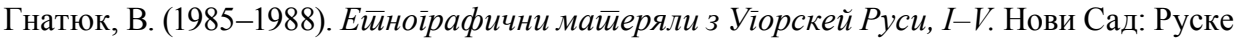
слово.

Lemkowie - kultura, sytuka, język - materialy z symposjuma (Sanok, 21 - 24 Wryeśnia, 1983). Sanok.

Mušinka, M. (1988). Kolesa sa krutia. Bigliografia v dvoch knihach. Prešov.

Струмінський, Б. (ред.) (1988). Лемківщина. Земля - люди - історія - культура. НьюЙорк-Париж-Сидней-Торонто.

Tamaš, J. (2002). Ukrajinska književnost između Istoka i Zapada. Novi Sad: Prometej - Ruske slovo.

Czambel, S. (1906). Slovenská reč a jej miesto v rodine slovanských jazikov (Vychodnoslovenské nárečie). Turčianský Sv. Matin: Nákladom vlastným. 
Julijan Tamaš

\section{THE LEMKO SUBSTRATE IN THE POETRIES OF B. I. ANTONIČ AND J. HARASIMOVIČ}

B. I. Antonič (1909-1937) writes poetry in Ukrainian, and J. Harasimovič (1933-1999) in Polish. Regardless of affiliation to various national poetic traditions, they share myth-creative nature. Both of them foster poetics of space. The first of them calls it the Green Gospel and the other calls it the Country Pleasantry. Lemko natural, cultural and poetic substrate is mutual. Under the Lemko substrate the author understands scintilla lyrica, kolomijka, krakovjak, basic emotionalizing of the world, the absence of heroic model of the world, social and historical split between civilized models of East and West, belonging to the Greek-Catholic Church etc.

Keywords: national poetics, poetics of space, myth-creative nature, happiness space, cultural substrate, individual poetics, epiclesis. 